Article

\title{
Soil Salinity Type Effects on the Relationship between the Electrical Conductivity and Salt Content for 1:5 Soil-to-Water Extract
}

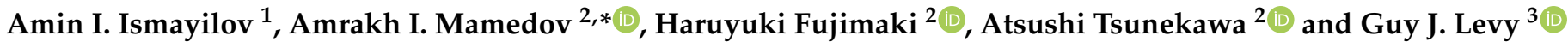 \\ 1 Institute of Soil Science and Agrichemistry, Azerbaijan National Academy of Sciences (ANAS), \\ Baku AZ1073, Azerbaijan; amin.ismayil@gmail.com \\ 2 Arid Land Research Center, Tottori University, Tottori 680-0001, Japan; fujimaki@tottori-u.ac.jp (H.F.); \\ tsunekawa@tottori-u.ac.jp (A.T.) \\ 3 Institute of Soil, Water and Environmental Sciences, ARO, Rishon LeZion 7505101, Israel; \\ vwguy@volcani.agri.gov.il \\ * Correspondence: amrakh03@yahoo.com
}

Citation: Ismayilov, A.I.; Mamedov, A.I.; Fujimaki, H.; Tsunekawa, A.; Levy, G.J. Soil Salinity Type Effects on the Relationship between the Electrical Conductivity and Salt Content for 1:5 Soil-to-Water Extract. Sustainability 2021, 13, 3395. https:// doi.org/10.3390/su13063395

Academic Editor: Adriano Sofo

Received: 22 February 2021

Accepted: 16 March 2021

Published: 19 March 2021

Publisher's Note: MDPI stays neutral with regard to jurisdictional claims in published maps and institutional affiliations.

Copyright: (c) 2021 by the authors. Licensee MDPI, Basel, Switzerland. This article is an open access article distributed under the terms and conditions of the Creative Commons Attribution (CC BY) license (https:// creativecommons.org/licenses/by/ $4.0 /)$.

\begin{abstract}
Soil salinity severely affects soil ecosystem quality and crop production in semi-arid and arid regions. A vast quantity of data on soil salinity has been collected by research organizations of the Commonwealth of Independent States (CIS, formerly USSR) and many other countries over the last 70 years, but using them in the current international network (irrigation and reclamation strategy) is complicated. This is because in the CIS countries salinity was expressed by total soluble salts as a percentage on a dry-weight basis (total soluble salts, TSS, \%) and eight salinity types (chemistry) determined by the ratios of the anions and cations $\left(\mathrm{Cl}^{-}, \mathrm{SO}_{4}{ }^{2-}, \mathrm{HCO}_{3}{ }^{-}\right.$, and $\mathrm{Na}^{+}$, $\mathrm{Ca}^{2+}, \mathrm{Mg}^{2+}$ ) in diluted soil water extract (soil/water $=1: 5$ ) without assessing electrical conductivity (EC). Measuring the EC (1:5) is more convenient, yet EC is not only affected by the concentration but also characteristics of the ions and the salinity chemistry. The objective of this study was to examine the relationship between EC and TSS of soils in a diluted extract (1:5) for eight classic salinity types. We analyzed extracts $(1: 5)$ of 1100 samples of a clayey soil $(0-20 \mathrm{~cm})$ collected from cultivated semi-arid and arid regions for EC, TSS, soluble cations $\left(\mathrm{Na}^{+}, \mathrm{Ca}^{2+}, \mathrm{Mg}^{2+}\right)$, and anions $\left(\mathrm{HCO}_{3}{ }^{-}, \mathrm{Cl}^{-}\right.$, $\left.\mathrm{SO}_{4}{ }^{2-}\right)$. Results revealed that (i) the variation in the proportional relationships $\left(\mathrm{R}^{2} \geq 0.91-0.98\right)$ between EC $\left(0.12-5.6 \mathrm{dS} \mathrm{m}^{-1}\right)$ and TSS $(0.05-2.5 \%)$ could be related to salinity type, and (ii) the proportionality coefficient of the relationships (2.2 2-3.16) decreased in the following order of salinity type: $\mathrm{SO}_{4}<\mathrm{Cl}\left(\mathrm{SO}_{4}\right)-\mathrm{HCO}_{3}<\mathrm{Cl}\left(\mathrm{HCO}_{3}\right)-\mathrm{SO}_{4}<\mathrm{SO}_{4}\left(\mathrm{HCO}_{3}\right)-\mathrm{Cl}<\mathrm{Cl}$. The findings suggest that once the salinity type of the soil is established, EC (1:5) values can be safely used for the evaluation of the soil salinity degree in the irrigated land in the context of sustainable soil and crop management.
\end{abstract}

Keywords: total dissolved salts; salinity chemistry; irrigation; dryland; salinity stress

\section{Introduction}

Cultivated lands, particularly in semi-arid and arid regions or drylands with scarce water resources, spread over more than 100 countries and $\sim 1$ billion ha (e.g., Argentina, Australia, China, India, USA) including the Commonwealth of Independent States (CIS, formerly USSR) are seriously affected by soil salinization and sodicity [1]. This environmental problem involves the ground water-soil-water-plant-atmosphere continuum associated with (i) water potential in the growth medium, which causes decreased transpiration and net photosynthetic rates (the osmotic effect, salinity degree), reduced capacity of plants to transform energy to biomass, and accumulation of specific toxic ions $\left(\mathrm{Cl}^{-}, \mathrm{Na}^{+}\right)$to levels exceeding the tolerance limits of plants (salinity stress, specific ion effect); (ii) ionic disequilibrium and imbalance of nutrients in the plant, thus harming seed germination, plant stomatal conductance, density and growth, and biomass partitioning between shoots and roots; and (iii) deterioration of soil structure (soil disaggregation and clay dispersion) 
and hydraulic characteristics (solution and air flow) due to high content of exchangeable $\mathrm{Na}^{+}, \mathrm{Mg}^{2+}$, or $\mathrm{K}^{+}$when soil electrolyte concentration is below a "threshold" level [2-5].

Plant tolerance to salinity varies with species and varieties and biotic and abiotic factors, yet the growth of most agricultural plants is negatively affected by salinity, which critically influences soil biological activities. The remediation of salt-affected soils, particularly secondary salinization, is expensive and difficult. Thus, plant response to soil salinity (both concentration and composition of the ions, i.e., osmotic stress and specific ion effects) and irrigation management should take the specific circumstances into account (e.g., leaching fraction, salinity stress, selection of cultivars tolerant to a certain salinity level, deterioration of soil physical quality, role of soil biota), and the interrelationships that exist among soil properties, salt composition, and plant species [2-6].

Assessing soil salinity is a critical task for the Kur-Araz basin (600,000 ha) of Azerbaijan, which is located in the shoreline area (situated below sea level up to $30 \mathrm{~m}$ with $<300-400 \mathrm{~mm}$ annual precipitation) and has wide drainage networks. Currently, $60 \%$ of the cultivated and irrigated land of the basin has clayey soil in the root zone and is characterized by various degrees and types of salinity (Figure 1) [7-9]. The problem of salinity in the Kur-Araz basin of Azerbaijan, as well as in many semi-arid and arid regions or drylands of the world, is expected to increase with the ongoing climate change and shortage in fresh water. Thus, frequent monitoring of salinity level is important for water resources allocation and sustainable management of salt-affected soils, which may have significant economic ramifications if ill-managed [10].

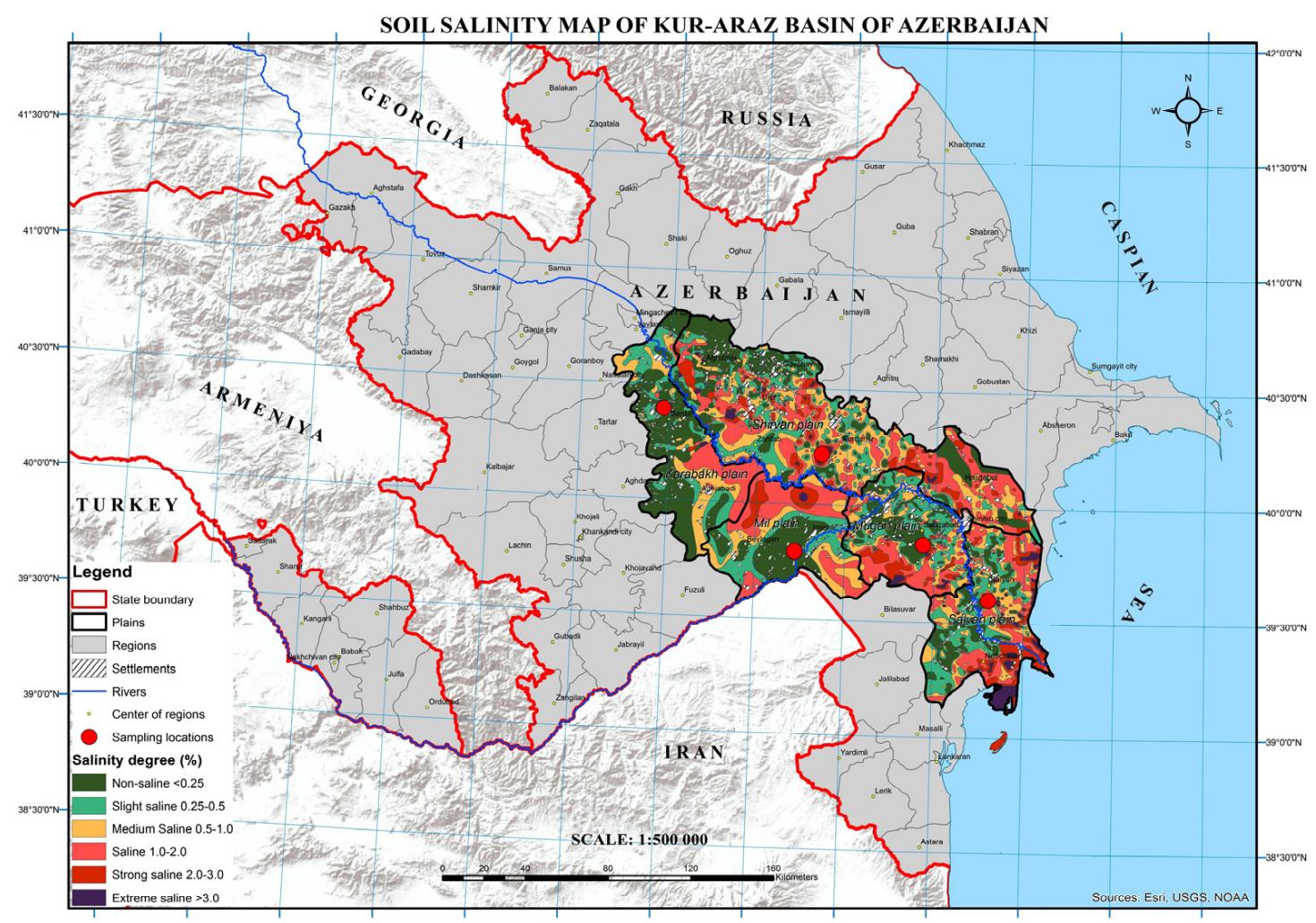

Figure 1. Soil salinity map of Kur-Araz basin of Azerbaijan (from [9]). Salinity degree is given by total soluble salts (TSS, \%). Salinity area $\left(10^{3}\right.$ ha): non-saline: 495.4 ; slightly saline: 381.8 ; saline: 414.6 ; strongly saline: 448.9 ; extremely saline: 174.4 .

Sustainability of the agroecosystem in salt-affected lands could be preserved by studying salinity related soil processes (e.g., the interactions between root-zone environment and plant response to elevated osmotic pressure, soil-plant-salinity interaction) and integrating new soil management and cropping systems resistant to drought and salinity stresses for effective soil function. Along with traditional reclamation (washing and amend- 
ing), use of microorganisms (e.g., rhizobacteria) may alleviate salinity stress by altering physiological changes in plants, yet soil microbial activity also depends on soil salinity and composition $[5,6]$. However, such approaches also require knowledge of previously collected information on soil salinity status (e.g., characteristics, distribution, and trend) for application of advanced approaches and precision agriculture across the various scales (e.g., GIS, remote sensing, digital mapping, geospatial analysis, electromagnetic induction) concerning salinity related management strategy $[11,12]$. Although the tolerance of plants to salinity strongly depends on the processes of accumulation and leaching of salts in the root zone, the impacts of salinity type (chemistry) associated with the predominant ions and salinity degree in soil solution and irrigation water are still overlooked $[2,3,5,6,10,13,14]$.

Saline soil classification by the USDA is based on the electrical conductivity of the saturated paste extract (ECe); a soil is considered saline if ECe $>4 \mathrm{dS} \mathrm{m}^{-1}$, exchangeable sodium percentage (ESP) $<15$, and $\mathrm{pH}<8.5$ [15] (Table 1). Determining ECe for salinity monitoring is related to natural conditions, but using it for the massive number of soil samples during the growing season is time-consuming and laborious. Therefore, researchers proposed to determine EC for various ratios of soil-to-water extracts (e.g., soil/water = 1:1, $1: 2,1: 2.5,1: 5)$ in the laboratory [16-21] (Table 1).

Table 1. US agronomic classification of soil salinity of the studied samples based on salinity of the saturated extract (ECe) [15] and that of the 1:5 soil/water extract (EC 1:5) [13].

\begin{tabular}{ccccc}
\hline Classification & ECe & Crop Yield & $\begin{array}{c}\text { EC (1:5) } \\
\text { dS m } \mathbf{~}^{-1}\end{array}$ & $\begin{array}{c}\text { Number of Samples } \\
\text { EC 1:5 }\end{array}$ \\
\hline NS $\mathbf{~ m}^{-\mathbf{1}}$ & $0-2$ & not affected & $0.0-0.25$ & 253 \\
Slightly saline & $2-4$ & sensitive crop affected & $0.25-0.5$ & 290 \\
Saline (moderate) & $4-8$ & many crops affected & $0.5-1.0$ & 170 \\
Strongly saline & $8-16$ & only tolerant crops & $1.0-2.0$ & 101 \\
Extremely saline & $>16$ & a few very tolerant crops & $>2.0-3.0$ & 286 \\
\hline
\end{tabular}

Many studies assessed the linear relationships between (i) ECe and EC (1:1, 1:2, 1:5); $\mathrm{ECe}=a \times \mathrm{EC}+b$, (ii) $\mathrm{EC}$ and total dissolved salts (TDS, $\mathrm{mg} \mathrm{L}^{-1}$ ) concentration: $\mathrm{TDS}=a \times \mathrm{ECe}$, and (iii) $\mathrm{EC}$ and solution ion components $\left(\mathrm{Na}^{+}, \mathrm{Ca}^{2+}, \mathrm{Mg}^{2+}, \mathrm{HCO}_{3}{ }^{-}, \mathrm{Cl}^{-}\right.$, $\left.\mathrm{SO}_{4}{ }^{2-}\right): \mathrm{EC}=a \times$ Ion (concentration) $+b$, yet the coefficients and intercepts $(a$ and $b)$ of the linear relationships for the similar studies varied between the regions $[2,18,22,23]$. The difference between the coefficients was associated along with the soil type, texture, presence of carbonate and gypsum, organic matter content, the method used for extract preparation, and the ratio of exchangeable cations and salinity chemistry [21,24-31]. Nevertheless, the relationship between EC of various soil/water extract ratios (1:1, 1:2, 1:2.5, 1:5) and particularly the use of EC (1:5) for quantifying soil salinity (TDS) is considered as an alternative simplified method commonly used in many countries $[10,23,32]$.

The EC of soil is not only determined by the concentration of ions but also by the characteristics of the ions or salinity chemistry $[11,15,33]$. Consequently, the ionic composition of the soil solution, in addition to the above attributes, should be taken into account for proper interpretation of salinity stress and soil-plant interactions $[2,3,5]$. In general, the CIS (and many other countries) classification of soil salinity (Table 2) is based on (i) salinity degree expressed as a percentage of salt in the soil on a dry-weight basis (total soluble salts, TSS, \%; g salt/100 g dry soil) and (ii) eight salinity types (i.e., salinity chemistry) determined by the concentration ratios of anions $\left(\mathrm{HCO}_{3}{ }^{-}, \mathrm{Cl}^{-}, \mathrm{SO}_{4}{ }^{2-}\right)$ and additionally by cations $\left(\mathrm{Na}^{+}, \mathrm{Ca}^{2+}, \mathrm{Mg}^{2+}\right)$ in 1:5 soil-water extraction (meq L ${ }^{-1}$ ), yet without measuring EC. This type of classification suggests that along with the TSS, the threshold level or toxicity of salts (highly soluble salts in toxic quantities to plants) is associated with the relationship between anionic and cationic ions, i.e., type and degree of salinity [33-35]. 
Table 2. Commonwealth of Independent States (CIS) classification of salt-affected soils according to the degree and salinity type $[10,14,34]$.

\begin{tabular}{|c|c|c|c|c|c|c|c|}
\hline \multicolumn{3}{|c|}{ Salinity Type } & \multicolumn{5}{|c|}{ Salinity, \% } \\
\hline Type & Ion Ratios & $\mathrm{pH}$ & Non & Slight & Moderate & Strong & Very Strong \\
\hline $\begin{array}{c}\text { Chloride }(\mathrm{Cl}) \\
\text { Sulfate-Chloride } \\
\left(\mathrm{SO}_{4}-\mathrm{Cl}\right)\end{array}$ & $\mathrm{Cl}: \mathrm{SO}_{4}>1$ & $\begin{array}{c}<8.5 \\
\text { neutral }\end{array}$ & $<0.05$ & $0.05-0.12$ & $0.12-0.35$ & $0.35-0.7$ & $>0.7$ \\
\hline $\begin{array}{l}\text { Chloride-Sulfate } \\
\quad\left(\mathrm{Cl}-\mathrm{SO}_{4}\right)\end{array}$ & $\mathrm{Cl}: \mathrm{SO}_{4}=0.2-1.0$ & $\begin{array}{c}<8.5 \\
\text { neutral }\end{array}$ & $<0.10$ & $0.10-0.25$ & $0.25-0.50$ & $0.50-1.0$ & $>1.0$ \\
\hline Sulfate $\left(\mathrm{SO}_{4}\right)$ & $\mathrm{Cl}: \mathrm{SO}_{4}<0.2$ & $\begin{array}{c}<8.5 \\
\text { neutral }\end{array}$ & $<0.15$ & $0.15-0.30$ & $0.30-0.60$ & $0.60-1.5$ & $>1.5$ \\
\hline $\begin{array}{l}\text { Chloride-Soda } \\
\left(\mathrm{Cl}-\mathrm{HCO}_{3}\right) \\
\text { Soda-Chloride } \\
\left(\mathrm{HCO}_{3}-\mathrm{Cl}\right)\end{array}$ & $\begin{array}{c}\mathrm{Cl}: \mathrm{SO}_{4}>1, \\
\mathrm{HCO}_{3}: \mathrm{Cl}>1 \\
\mathrm{HCO}_{3}>\mathrm{Ca}+\mathrm{Mg}\end{array}$ & $\begin{array}{c}>8.5 \\
\text { alkaline }\end{array}$ & $<0.10$ & $0.10-0.15$ & $0.15-0.30$ & $0.30-0.5$ & $>0.5$ \\
\hline $\begin{array}{l}\text { Sulfate-Soda } \\
\left(\mathrm{SO}_{4}-\mathrm{HCO}_{3}\right) \\
\text { Soda-Sulfate } \\
\left(\mathrm{HCO}_{3}-\mathrm{SO}_{4}\right)\end{array}$ & $\begin{array}{c}\mathrm{Cl}: \mathrm{SO}_{4}<1 \\
\mathrm{HCO}_{3}: \mathrm{Cl}>1 \\
\mathrm{HCO}_{3}>\mathrm{Ca}+\mathrm{Mg}\end{array}$ & $\begin{array}{c}>8.5 \\
\text { alkaline }\end{array}$ & $<0.15$ & $0.15-0.25$ & $0.25-0.40$ & $0.40-0.6$ & $>0.6$ \\
\hline
\end{tabular}

A vast quantity of data on soil salinity (TSS and ion composition, soil/water ratio $=1: 5$ ) has been collected by research and other relevant organizations in the CIS and other countries, including Azerbaijan, during the past 70 years. However, using these data in current international scientific networks (and irrigation and reclamation strategy) is complicated due to the lack of EC measurements and proper linkage to the quantity of soluble salts (TSS). To the best of our knowledge, this is the first work that attempts to investigate the relationship between EC and TSS in association with salinity type (chemistry). This activity is of great importance for assessing various advanced practical activities and contributing to sustainable agriculture in the salt-affected fields in support of increasing crop yield, obtaining and analyzing digital mapping, determination of leaching fraction, combining waters of diverse quality for irrigation, etc. [36]. We hypothesized that for a 1:5 soil/water extract, the association between the EC and TSS varies among soils differing in their salinity chemistry. Therefore, the objective of this study was to evaluate the relationship between EC $\left(\mathrm{dS} \mathrm{m}^{-1}\right)$ and TSS (\%) of soil-water extract (1:5) with consideration of eight salinity types, available in the Kur-Araz basin. It should be noted that the relationships between the EC (1:5) and ECe (or EC (1:1), EC (1:2)), as well as between EC ( $\mathrm{dS} \mathrm{m}^{-1}$ ) and TDS $\left(\mathrm{mg} \mathrm{L}^{-1}\right)$ or TSS $\left(\%\right.$ or meq L $\left.{ }^{-1}\right)$ and between EC and typical ion composition $\left(\mathrm{Na}^{+}, \mathrm{Ca}^{2+}\right.$, $\mathrm{Mg}^{2+}, \mathrm{HCO}_{3}{ }^{-}, \mathrm{Cl}^{-}, \mathrm{SO}_{4}{ }^{2-}$ ) are the subject of another ongoing study, which also compares results of new experiments with well-established relationships from the literature for similar climate and soil types and textures $[1,18,23,29,32,37]$.

\section{Materials and Methods}

A total of 1100 soil samples (taken from a 0-20 cm depth), representing mostly irrigated soils of different salinity types and levels, were collected from five plan areas (Salyan: $49^{\circ} 03^{\prime} 4.81^{\prime \prime}$ E, $39^{\circ} 35^{\prime} 54.01^{\prime \prime}$ N; Shirvan: $48^{\circ} 05^{\prime} 15.75^{\prime \prime}$ E, $40^{\circ} 13^{\prime} 9.17^{\prime \prime}$ N; Mil: $47^{\circ} 57^{\prime} 01.51^{\prime \prime}$ E,

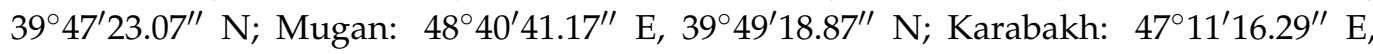
$40^{\circ} 23^{\prime} 45.86^{\prime \prime} \mathrm{N}$ ) in the Kur-Araz basin of Azerbaijan (semi-arid and arid region) during the spring period (Figure 1). Soils were used under different types of crop cultivation and were characterized by gray-meadow and meadow-gray soil types (associated with FAO Calcisols), clayey texture, and low organic matter content. Eight types of salinity chemistry (Table 2) were formed in light of the geology and geomorphological and environmental conditions, cultivation, irrigation, and drainage history in the basin $[7,8]$.

The samples were oven-dried, ground, and then passed through a $2 \mathrm{~mm}$ sieve. Then, $250 \mathrm{~mL}$ of distilled water was added to $50 \mathrm{~g}$ of soil, and the suspension was shaken for $1 \mathrm{~min}$ by hand 4 times with $30 \mathrm{~min}$ intervals. The suspensions were left afterwards to reach 
equilibrium for $4 \mathrm{~h}$, and soon thereafter the extract was obtained by filtering. Analyses of soil salinity included EC soluble cations $\left(\mathrm{Na}^{+}, \mathrm{Ca}^{2+}, \mathrm{Mg}^{2+}\right)$ and anions $\left(\mathrm{HCO}_{3}{ }^{-}, \mathrm{Cl}^{-}\right.$, $\mathrm{SO}_{4}{ }^{2-}$ ) in the prepared 1:5 soil/water extracts [38]. Soil TSS, the mass of salt in the extracted solution, was determined by evaporating and subsequent completion of dryness in an oven $\left(\right.$ at $70{ }^{\circ} \mathrm{C}$ ) and weighing. Statistical analyses were performed using the SAS Proc GLM procedure [39], where mean comparisons were performed using the Tukey-Kramer honestly significant difference HSD test at $p<0.05$. Least squares fitting was applied to identify the relationship between soil TSS and EC for 1:5 soil-to-water extracts.

\section{Results}

Generally, for the salinity types of the samples presented in Table 2, sulfate $\left(\mathrm{SO}_{4}\right)$ salinity types coupled with low-to medium exchangeable sodium percentage $(\mathrm{ESP}=2-10)$ were found mostly in Shirvan plain with various levels of gypsum, whereas mixed soda (carbonate and bicarbonate) related salinity types $\left(\mathrm{Cl} / \mathrm{SO}_{4}-\mathrm{HCO}_{3} ; \mathrm{HCO}_{3}-\mathrm{Cl} / \mathrm{SO}_{4}\right)$ coupled with low-to-elevated ESP (2-40) occurred mostly in Karabakh and infrequently in Mil plains, and chloride-sulfate $\left(\mathrm{Cl}-\mathrm{SO}_{4}\right)$ and sulfate-chloride $\left(\mathrm{SO}_{4}-\mathrm{Cl}\right)$ salinity types, coupled with low-to-medium ESP (2-15), which dominated in Mugan and Salyan and Shirvan plains of the Kur-Araz basin (Figure 1) [7,8]. The relationship between EC (1:5) and TSS (total soluble salts, \%) for eight salinity types (chemistry) is presented in Figures 2 and 3.
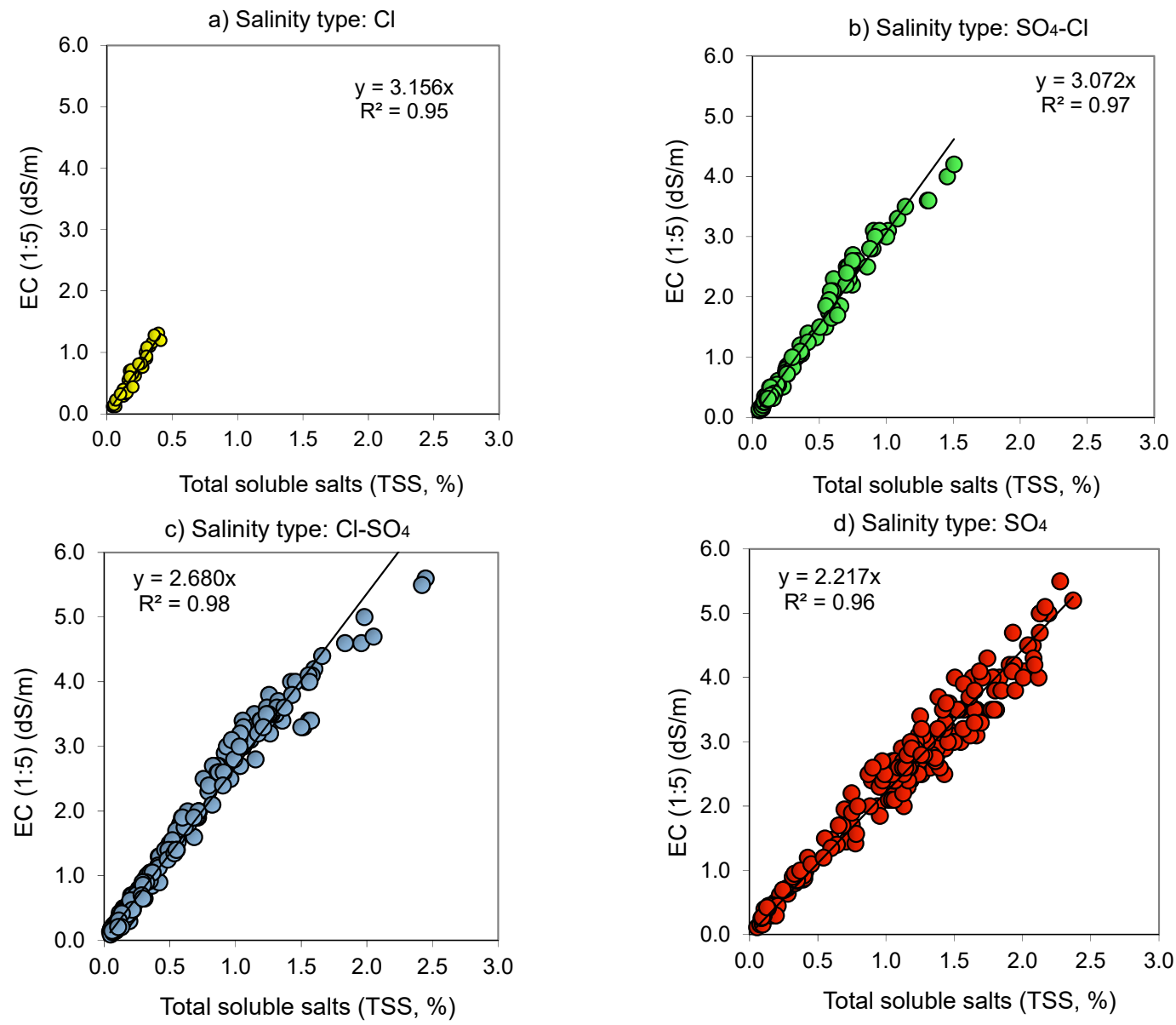

Figure 2. Relationship $(p<0.001)$ between the electrical conductivity (EC 1:5, $\left.\mathrm{dS} \mathrm{m} \mathrm{m}^{-1}\right)$ and total soluble salt content (TSS, \% or g salt $/ 100 \mathrm{~g}$ soil) for 1:5 soil-to-water extract as affected by neutral $(\mathrm{pH}<8.5)$ salinity type: $(\mathbf{a}) \mathrm{Chloride}(\mathrm{Cl})$; (b) Sulfate-Chloride $\left(\mathrm{SO}_{4}-\mathrm{Cl}\right)$; (c) Chloride-Sulfate $\left(\mathrm{Cl}-\mathrm{SO}_{4}\right)$; and (d) Sulfate $\left(\mathrm{SO}_{4}\right)$. 

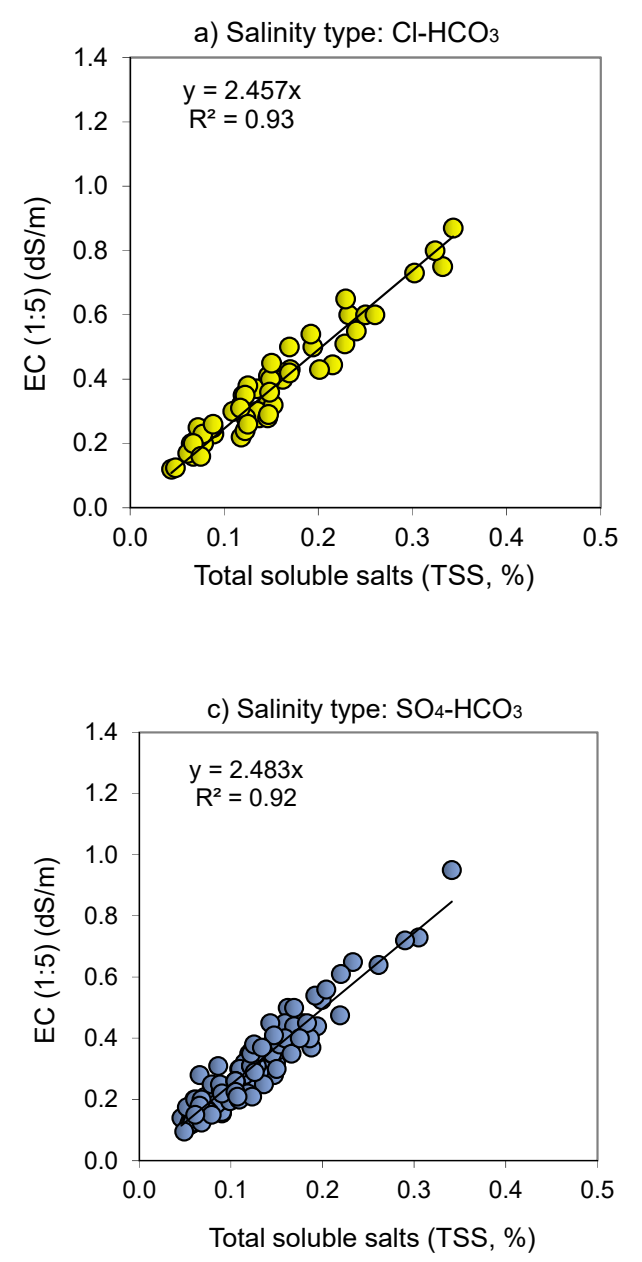

b) Salinity type: $\mathrm{HCO}_{3}-\mathrm{Cl}$
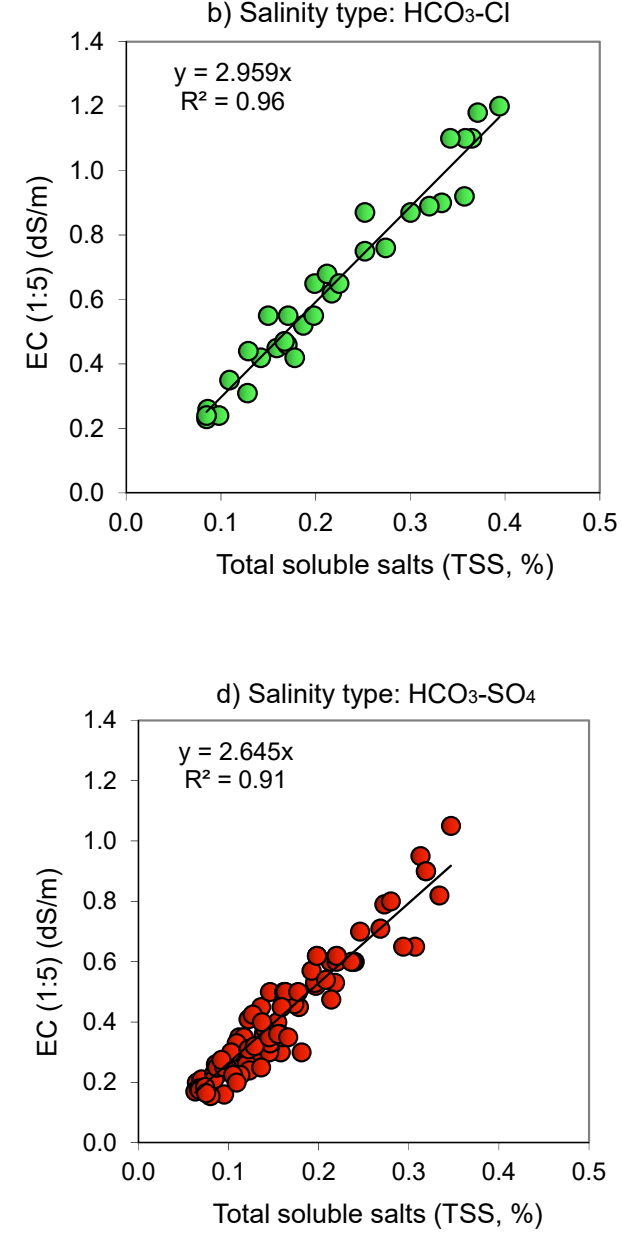

Figure 3. Relationship $(p<0.001)$ between the electrical conductivity $\left(\mathrm{EC} 1: 5, \mathrm{dS} \mathrm{m}^{-1}\right)$ and total soluble salt content (TSS, \% or g salt/100 g soil) for 1:5 soil-to-water extract as affected by alkaline $(\mathrm{pH}>8.5)$ salinity type: (a) Chloride-Soda $\left(\mathrm{Cl}_{-} \mathrm{HCO}_{3}\right)$; (b) Soda-Chloride $\left(\mathrm{HCO}_{3}-\mathrm{Cl}\right)$; (c) Sulfate-Soda $\left(\mathrm{SO}_{4}-\mathrm{HCO}_{3}\right)$; and (d) Soda-Sulfate $\left(\mathrm{HCO}_{3}-\mathrm{SO}_{4}\right)$.

The EC of neutral $(\mathrm{pH}<8.5)$ salinity types varied widely between 0.12 and $5.6 \mathrm{dS} \mathrm{m}^{-1}$ except for the $\mathrm{Cl}$ salinity type (Figure 2), yet it varied to a lesser extent, between 0.11 and $1.2 \mathrm{dS} \mathrm{m}^{-1}$, in the alkaline ( $\left.\mathrm{pH}>8.5\right)$ salinity types (Figure 3 ). The fitted line presents the proportional relation (EC $=a \times$ TSS) between the two attributes, with $a$ being the proportionality coefficient (Figures 2 and 3). Because intersects of relationships were negligible, we opted to use the proportional type relation as it is easy to explore. Due to soil salinization-desalinization environmental processes, there were not enough available samples (e.g., locations) or just a limited number of samples exhibiting strongly saline (EC $(1: 5)=1-2 \mathrm{dS} \mathrm{m}^{-1}$ ) and extremely saline (EC (1:5) $>2 \mathrm{dS} \mathrm{m}^{-1}$ ) levels from (i) neutral soils with easily washed $\mathrm{Cl}$ salinity type (Figure 2 ) and (ii) alkaline soils having $\mathrm{SO}_{4}(\mathrm{Cl})-\mathrm{HCO}_{3}$ and $\mathrm{HCO}_{3}-\mathrm{SO}_{4}(\mathrm{Cl})$ type of salinity (Figure 3 ).

Low level of salinity was related to soils under long-term cultivation with drainage setup, irrigation with substantial amount of fresh water, or with pre-vegetation winter leaching by flooding. High levels of salinity usually were related to (i) salinity spots in irrigated fields with deficit of irrigation, (ii) ineffective irrigation and drainage setup, and (iii) unused slat-affected areas located near cultivated fields, with superior evaporation over rainfall $[7,8,40,41]$. Long periods of irrigation practices and leaching processes under annual crops may change soil salinity degree, $\mathrm{pH}$ and ion composition, and exchangeable cations, and consequently salinity type. Intensity and direction of the processes depend on soil properties, irrigation and groundwater quality, irrigation depth, depth of 
groundwater [40,41], and content of carbonates (2-20\%) and gypsum $(0.2-3 \%)$ typically present in the soils of the Kur-Araz basin $[7,8]$.

Though soil EC 1:5 was proportional to its salt content (i.e., TSS, \%) in all the salinity types, there were differences in the proportionality coefficient $(a=2.22-3.16)$ (Figures 2 and 3, Table 3). The coefficient $a$ increased in the following order: $\mathrm{SO}_{4}<\mathrm{Cl}\left(\mathrm{SO}_{4}\right)^{-}$ $\mathrm{HCO}_{3}<\mathrm{Cl}\left(\mathrm{HCO}_{3}\right)-\mathrm{SO}_{4}<\mathrm{SO}_{4}\left(\mathrm{HCO}_{3}\right)-\mathrm{Cl}<\mathrm{Cl}$. The proportionality coefficient for conversion from TSS (\%) to EC (1:5) ( $\left.\mathrm{dS} \mathrm{m}^{-1}\right)$ varied between 0.313 to 0.447 and decreased in the following order: $\mathrm{SO}_{4}>\mathrm{Cl}\left(\mathrm{SO}_{4}\right)-\mathrm{HCO}_{3}>\mathrm{Cl}\left(\mathrm{HCO}_{3}\right)-\mathrm{SO}_{4}>\mathrm{SO}_{4}\left(\mathrm{HCO}_{3}\right)-\mathrm{Cl}>\mathrm{Cl}$ (Table 3). In both related cases, difference in the proportionality coefficient could be related to salinity characteristics [35].

Table 3. Proportionality coefficients (a) of linear relationship between electrical conductivity (EC $1: 5, \mathrm{dS}^{-1}$ ) and total soluble salts (TSS, \%). Within a column, numbers followed by the same letter do not differ significantly at $p<0.05$.

\begin{tabular}{|c|c|c|c|c|c|c|c|c|}
\hline \multirow[b]{2}{*}{ Salinity Type } & \multirow[b]{2}{*}{ Number of Samples } & \multirow[b]{2}{*}{$\mathrm{pH}$} & \multicolumn{2}{|c|}{ Salinity Range } & \multicolumn{2}{|c|}{$\mathrm{EC}=a \mathrm{TSS}$} & \multicolumn{2}{|c|}{$\mathrm{TSS}=a \mathrm{EC}$} \\
\hline & & & $\begin{array}{c}\text { TSS } \\
\%\end{array}$ & $\begin{array}{c}\text { EC 1:5 } \\
\mathrm{dS} \mathrm{m}^{-1}\end{array}$ & $a$ & $\begin{array}{c}R^{2} \\
p<0.001\end{array}$ & $a$ & $\begin{array}{c}R^{2} \\
p<0.001\end{array}$ \\
\hline $\mathrm{Cl}$ & 32 & $<8.5$ & $0.044-0.414$ & $0.120-1.20$ & $3.156 \mathrm{a}$ & 0.95 & $0.313 \mathrm{e}$ & 0.94 \\
\hline $\mathrm{SO}_{4}-\mathrm{Cl}$ & 96 & $<8.5$ & $0.050-1.504$ & $0.135-4.20$ & $3.072 \mathrm{ab}$ & 0.97 & $0.323 \mathrm{e}$ & 0.97 \\
\hline $\mathrm{Cl}-\mathrm{SO}_{4}$ & 390 & $<8.5$ & $0.046-2.448$ & $0.140-5.60$ & $2.680 \mathrm{c}$ & 0.98 & $0.369 \mathrm{~d}$ & 0.98 \\
\hline $\mathrm{SO}_{4}$ & 246 & $<8.5$ & $0.054-2.369$ & $0.115-5.20$ & $2.217 \mathrm{e}$ & 0.96 & $0.447 \mathrm{a}$ & 0.96 \\
\hline $\mathrm{Cl}-\mathrm{HCO}_{3}$ & 56 & $>8.5$ & $0.044-0.343$ & $0.120-0.87$ & $2.457 \mathrm{~d}$ & 0.93 & $0.402 \mathrm{~b}$ & 0.93 \\
\hline $\mathrm{HCO}_{3}-\mathrm{Cl}$ & 32 & $>8.5$ & $0.085-0.394$ & $0.230-1.20$ & $2.959 \mathrm{~b}$ & 0.96 & $0.336 \mathrm{e}$ & 0.95 \\
\hline $\mathrm{SO}_{4}-\mathrm{HCO}_{3}$ & 144 & $>8.5$ & $0.046-0.341$ & $0.140-0.95$ & $2.483 \mathrm{~d}$ & 0.92 & $0.396 \mathrm{c}$ & 0.91 \\
\hline $\mathrm{HCO}_{3}-\mathrm{SO}_{4}$ & 104 & $>8.5$ & $0.063-0.347$ & $0.170-1.05$ & $2.645 \mathrm{c}$ & 0.91 & $0.371 \mathrm{~d}$ & 0.91 \\
\hline All & 1100 & & $0.044-2.448$ & $0.115-5.60$ & $2.401 \mathrm{~d}$ & 0.96 & $0.408 \mathrm{~b}$ & 0.96 \\
\hline
\end{tabular}

\section{Discussion}

Differences in the proportionality coefficient $(a=2.22-3.16)$ of the linear relationship between EC (1:5) $\left(\mathrm{dS} \mathrm{m}^{-1}\right)$ and TSS (\%) (EC $=a \times$ TSS, Table 3, Figures 2 and 3) were associated with salinity type (chemistry), and ion specific concentration and conductivity, and presence of gypsum or lime, as samples have similar soil texture [35]. The effect of each ion on the EC and TSS relationship is related to its size. Generally, for the same concentration (meq $\mathrm{L}^{-1}$ ), the conductivity of multi-charged and larger ions is smaller than that of smaller single-charged ions; thus, the larger anions $\mathrm{SO}_{4}{ }^{2-}$ and $\mathrm{HCO}_{3}{ }^{-}$have lower conductivity (Figures $2 \mathrm{~d}$ and $3 \mathrm{c}, \mathrm{d}$ ) than the smaller $\mathrm{Cl}^{-}$anion (Figures $2 \mathrm{a}, \mathrm{b}$ and $3 \mathrm{~b}$ ). However, the divalent cations $\left(\mathrm{Ca}^{2+}\right.$ and $\left.\mathrm{Mg}^{2+}\right)$ have higher conductivity than the monovalent cations $\left(\mathrm{Na}^{+}\right.$and $\mathrm{K}^{+}$) [13]. The relationship between EC (1:5) and TSS (\%) is also affected by the dilution factor of the solution, since by increasing the water/soil ratio, the degree of dissolution of the slightly soluble $\mathrm{CaSO}_{4}$ and $\mathrm{CaCO}_{3}$ increases and thus affects the concentration of the salts (TSS) and ratio of the soluble ions, as well as the composition of the exchangeable ions. Our results were in agreement with previous studies, reporting that the relationships between ECe and EC (1:5) or EC (1:1, 1:2), as well as EC and TDS (mg L ${ }^{-1}$ ) or TSS (meq L $\mathrm{L}^{-1}$ or $\%$ ), for the diluted extract were associated with presence of lime and gypsum and various salts, although different extraction protocols and sampling periods (soil moisture condition) have been used [1,6,11,21,23,26,27,32,42].

In support of the abovementioned conclusion, it should be noted that although no fixed relationships existed between ECe $\left(\mathrm{dS} \mathrm{m}^{-1}\right)$ and total dissolved solid $\left(\mathrm{mg} \mathrm{L}^{-1}\right)$, a coefficient of 640 (EC $<5 \mathrm{dS} \mathrm{m}^{-1}$ ) is commonly used (established for Western US soils) to convert ECe to total dissolved solid $\left(\mathrm{mg} \mathrm{L}^{-1}\right)[15,22,32]$. This relationship, which was developed in a system where $\mathrm{Cl}^{-}$was the dominant anion, may overestimate or underestimate the concentration of the TDS in the extracts, largely varying in salt species (e.g., for the $\mathrm{Cl}-\mathrm{HCO}_{3}, \mathrm{Cl}-\mathrm{SO}_{4}$ and $\mathrm{SO}_{4}$ system) $[2,13,22]$. For instance, in gypsum-rich soils, the quantity of extracted salts could be reduced by the quantity of water used due to the limited solubility, and the slow rate of dissolution of $\mathrm{CaSO}_{4}$; for the gypsum-rich semi-arid soils of Canada (260 samples, EC $=0.1-16 \mathrm{dS} \mathrm{m}^{-1}$ ), the coefficient of relationship 
between ECe and TDS was much higher (924 vs. 640) than the commonly used one [22]. In other relevant studies, soil texture and gypsum $\left(4-25 \mathrm{cmol} \mathrm{kg}^{-1}\right)$ significantly modified the relationship between ECe and EC (1:2) or EC (1:5) in soils from the arid region of Iran ( $>250$ samples, $\mathrm{ECe}=1-33 \mathrm{dS} \mathrm{m}^{-1}$ ); the coefficient of the linear relation was significantly higher for the samples with gypsum, which has greater impact (than soil texture) on the accuracy of predicting ECe [27,37]. In arid soils from Turkey $\left(E C e=0.4-16 \mathrm{dS} \mathrm{m}^{-1}\right)$, the coefficient of the linear relationship between ECe and EC (1:1: 1:2.5; 1:5) increased $>3$ times with the change in soil/water ratio from 1:1 to 1:5, whereas change in soil texture from sandy to clay soil reduced by $\sim 1.2$ times the mean of the coefficients. Similar results were reported by scientists from Greece and the US [18,21,42]. In the examples of the related studies $[13,20-23,27,37,42]$ the coefficients of determination for the relationship between ECe and TDS, and ECe and EC (1:1: 1:2; 1:2.5; 1:5), were mostly strong $\left(R^{2} \geq 0.90\right)$.

Our proportionality coefficient ( $a$, with a mean of 0.408 ) between TSS (\%) and EC (1:5) $\left(\mathrm{dS} \mathrm{m}^{-1}\right)$ was as expected and salinity-type-dependent (Table 3$)$. The internationally reported mean value of conversion (TSS $=\mathrm{g}$ salt $/ 100 \mathrm{~g}$ dry soil, or $\%=0.336 \mathrm{EC}(1: 5$, $\left.\mathrm{dS} \mathrm{m}^{-1}\right)$ ) is based on soil salinity dominated by $\mathrm{NaCl}$ with the possible presence of some $\mathrm{SO}_{4}{ }^{2-}$ anions [13]. This value (0.336) was significantly lower than our mean value (0.408) but still within the range of coefficients obtained in the current study (0.313-0.447). Thus, in relation to the coefficients obtained in our study (Table 3), the international coefficient was (i) comparable (slightly higher) for chloride itself and chloride dominant salinity type (0.313, 0.323 , and 0.336 for $\mathrm{Cl}, \mathrm{SO}_{4}-\mathrm{Cl}$, and $\mathrm{HCO}_{3}-\mathrm{Cl}$, respectively); (ii) similar but somewhat lower for the sulfate dominant type of salinity ( 0.369 and 0.371 for $\mathrm{Cl}_{-} \mathrm{SO}_{4}$ and $\mathrm{HCO}_{3}-\mathrm{SO}_{4}$, respectively); and (iii) lower for sulfate itself and the soda (carbonate and bicarbonate) dominant type of salinity $\left(0.447,0.402\right.$, and 0.396 for $\mathrm{SO}_{4}, \mathrm{Cl}-\mathrm{HCO}_{3}$, and $\mathrm{SO}_{4}-\mathrm{HCO}_{3}$, respectively), all typically present in different parts of the Kur-Araz basin [8]. The deviation of the mean, a value of 0.408 , from the internationally reported one, may also stem from the weighted number of the samples used for each salinity type in our study. Nevertheless, the number of samples for non-saline, slightly saline, saline + strongly saline, and extremely saline (253-290) (Table 1 ) in the current study seems large enough $[15,22,37]$ to ensure sufficient confidence in the significant relationship obtained between TSS and EC $(1: 5)$ and the resultant proportionality coefficient (a) arising from our study.

The influence of salinity on plant growth is mainly based on ECe, so it is necessary to convert EC 1:5 to ECe in order to assess plant response. When there are no available or limited data on soil EC (extract, 1:1, 1:2) and TDS for a given investigated region, then as an initial step or for approximate computation, the obtained relationships from the current study (EC (1:5) $=a \times$ TSS, Table 3) could be used to establish numerous relationships between EC and TDS (or TSS) and between EC and typical salt type from semi-arid and arid regions, for planning of management and irrigation and reclamation strategy $[18,20,21,23,27,31,32]$.

Salinity is a dynamic soil property within the root zone. Evaporation from the soil surface and plant transpiration remove soil water, which concentrates salts in the soil solution. Moreover, dissolved salts within the soil profile are mobile due to convective-dispersive and diffusion processes. Therefore, the main issues in sustainable soil management under irrigation for maintaining crop or plant productivity are somewhat complex as they relate on one hand to preventing excessive salt accumulation in the root zone and on the other to minimizing excess drainage of water (with salts and nutrients) below the root zone, while maintaining soil quality (physical, chemical, and biological) and minimizing off-site effects are required $[5,6]$.

In the studied Kur-Araz basin, it has been observed over recent years that the decrease in total salinity (EC and TSS) is coupled with ion exchange between soil solution and solid phase of soil and shifts in the chemistry of the salts (e.g., from $\mathrm{Cl}, \mathrm{SO}_{4}-\mathrm{Cl}$, and $\mathrm{HCO}_{3}-\mathrm{Cl}$ to $\mathrm{Cl}-\mathrm{SO}_{4}, \mathrm{Cl}-\mathrm{HCO}_{3}$, and $\mathrm{SO}_{4}-\mathrm{HCO}_{3}$, respectively) during irrigation, rain events, and amelioration processes (e.g., accelerated leaching of salts by intense drainage condition and flooding, adding leaching fraction to irrigation water, or using salt tolerant plants and 
microbiota), which result in the leaching of highly soluble salts and hence alter the ratios of cations and anions and affect plant adaptation and growth [2,15]. Consequently, the abovementioned changes are associated with lower soil salinity (below the threshold level for particle flocculation, particularly during rains with very low EC), which may cause clay dispersion and aggregate slaking. These processes can increase soil alkalinity or sodicity after a certain period of time and lead to deterioration of soil physical quality, particularly in clayey soils $[4,40,41,43]$. In the case of formation of a soda (carbonate or bicarbonate: $\mathrm{CO}_{3}{ }^{2-}$ and $\mathrm{HCO}_{3}{ }^{-}$) dominated salinity type, poor soil structure and physical properties hinder the leaching process [43,44], plant growth, and productivity in the soils of the basin, particularly in Karabakh and Mil plains [40,41]. Finally, understanding of the complex relationship between the salinity parameters, including salinity chemistry, involved in ecosystem services (crop production, soil and water conservation, and environmental pollution) and quantifying the associated chemical and mineralogical processes operating in soil water systems are crucial to building sustainable agricultural systems for semi-arid and arid regions $[5,12,32,36]$.

\section{Conclusions}

Developing an integrated and sustainable management strategy in saline soils requires a systematic study of the processes and factors contributing to salinity parameters for identifying and implementing water-saving and soil-improvement measures based on soil salinity and water-saving irrigation approaches. Our findings suggest that once the salinity type of the soil is established, EC (1:5) values can be used for the evaluation of the soil salinity degree in cultivated and irrigated land in the context of sustainable soil and crop management. While the general EC and TSS (or TDS) relationship may help in achieving salinity management and control under irrigation and amelioration, soil properties and other factors affecting soil salinity dynamics and salinity type should be considered to control salinity level, soil hydraulic properties and structural status under field conditions. Such knowledge can assist in the development of sustainable management practices for irrigated lands and thus maintain crop growth and productivity.

Author Contributions: Conceptualization, A.I.I., A.I.M.; methodology, A.I.I., A.I.M.; G.J.L.; software, A.I.M. and H.F.; validation, A.I.I., A.T. and G.J.L.; formal analysis, A.T., and H.F.; investigation, A.I.I.; resources, A.T., H.F. and A.I.I.; data curation, A.I.I. and H.F.; writing-original draft preparation, A.I.I., A.I.M., G.J.L., H.F.; writing-review and editing, A.I.I., A.I.M., G.J.L., H.F., A.T.; visualization, A.I.I.; supervision, A.I.I. and A.T.; project administration, A.I.I. and A.T.; funding acquisition, A.T. and H.F. All authors have read and agreed to the published version of the manuscript.

Funding: This research received no external funding. The authors thank Arid Land Research Center, Tottori University and Institute of Soil Science and Agrochemistrty, ANAS, for the financial support.

Institutional Review Board Statement: Not applicable.

Informed Consent Statement: Not applicable.

Conflicts of Interest: The authors declare no conflict of interest.

\section{References}

1. Shahid, S.A. Developments in salinity assessment, modeling, mapping, and monitoring from regional to submicroscopic scales. In Developments in Soil Salinity Assessment and Reclamation-Innovative Thinking and Use of Marginal Soil and Water Resources in Irrigated Agriculture; Shahid, S.A., Abdelfattah, M.A., Taha, F.K., Eds.; Springer: Dordrecht/Heidelberg, Germany; New York, NY, USA; London, UK, 2013; pp. 3-43.

2. Bresler, E.; McNeal, B.L.; Carter, D.L. Saline and Sodic Soils; Advanced Series in Agricultural Sciences; Springer: Berlin/Heidelberg, Germany, 1982; Volume 10, 236p.

3. Van Straten, G.; de Vos, A.C.; Rozema, J.; Bruning, B.; van Bodegom, P.M. An improved methodology to evaluate crop salt tolerance from field trials. Agric. Water Manag. 2019, 213, 375-387. [CrossRef]

4. Levy, G.J.; Mamedov, A.I.; Goldstein, D. Sodicity and water quality effects on slaking of aggregates from semi-arid soils. Soil Sci. 2003, 168, 552-562. [CrossRef]

5. Rengasamy, P. Soil processes affecting crop production in salt affected soils. Funct. Plant Biol. 2010, 37, 613-620. [CrossRef] 
6. $\quad$ Egamberdieva, D.; Wirth, S.; Bellingrath-Kimura, S.D.; Mishra, J.; Arora, N.K. Salt-tolerant plant growth promoting rhizobacteria for enhancing crop productivity of saline soils. Front. Microbiol. 2019, 10, 2791. [CrossRef] [PubMed]

7. Khasayev, G.A.; Madyashov, A.G. Summary of the possibilities for improving the efficiency of implementing measures for sa-line lands desalination. Taurida Sci. Herald 2018, 104, 208-219. (In Russian with English abstract)

8. Azizov, G.Z. Classification of Saline Soils of Azerbaijan According to the Degree and Type of Salinity; Elm: Baku, Azerbaijan, 2002; (In Russian with English abstract).

9. Ismayilov, A.; Yashar, A. Analysis of the relief role in the Kur-Araz lowland soils salinity based on GIS technology. In Proceedings of the Eurasian GIS Congress, Baku, Azerbaijan, 4-7 September 2018; pp. 294-297.

10. Omuto, C.T.; Vargas, R.R.; El Mobarak, A.M.; Mohamed, N.; Viatkin, K.; Yigini, Y. Mapping of Salt-Affected Soils; Technical manual; FAO: Rome, Italy, 2020; 131p. [CrossRef]

11. Hammam, A.A.; Mohamed, E.S. Mapping soil salinity in the East Nile Delta using several methodological approaches of salinity assessment. Egypt. J. Remote Sens. Space Sci. 2018, 23, 125-131. [CrossRef]

12. Corwin, D.L.; Scudiero, E. Review of soil salinity assessment for agriculture across multiple scales using proximal and/or remote sensors. In Advances in Agronomy; Elsevier: Amsterdam, The Netherlands, 2019; Volume 158, pp. 1-130. [CrossRef]

13. Hazelton, P.; Murphy, B. Interpreting Soil Test Results. What Do All the Numbers Mean? CSIRO Publishing: Collingwood, Australia, 2016; 200p. [CrossRef]

14. Pankova, E.I.; Vorobieva, L.A.; Balyuk, S.A.; Khasankhanova, G.M.; Konyushkova, M.V.; Yamnova, I.A. Salt-affected soils of the Eurasian Region: Fdiagnostics, criteria and distribution. In Handbook for Saline Soil Management; Vargas, R., Pankova, E.I., Balyuk, S.A., Krasilnikov, P.V., Khasankhanova, G.M., Eds.; FAO: Rome, Italy, 2018; pp. 3-15. Available online: http: //www.fao.org/3/I7318EN/i7318en.pdf (accessed on 10 September 2018).

15. United States Salinity Laboratory. Diagnoses and Improvement of Saline and Alkali Soils; Agriculture Handbook No 60; USDA: Washington, DC, USA, 1954; 160p.

16. Hogg, T.J.; Henry, J.L. Comparison of 1:1 and 1:2 suspensions and extracts with the saturation extracts in estimating salinity in Saskatchewan. Can. J. Soil Sci. 1984, 64, 699-704. [CrossRef]

17. Zhang, H.; Schroder, J.L.; Pittman, J.J.; Wang, J.J.; Payton, M.E. Soil salinity using saturated paste and 1:1 soil to water extract. Soil Sci. Soc. Am. J. 2005, 69, 1146-1151. [CrossRef]

18. Sonmez, J.S.; Buyuktas, D.; Okturen, F.; Citak, S. Assessment of different soil to water ratios (1:1, 1:2:5, 1:5) in soil salinity studies. Geoderma 2008, 144, 361-369. [CrossRef]

19. He, Y.; DeSutter, T.; Prunty, L.; Hopkins, D.; Jia, X.; Wysocki, D. Evaluation of 1:5 soil to water extract electrical conductivity methods. Geoderma 2012, 185-186, 12-17. [CrossRef]

20. Matthees, H.L.; He, Y.; Owen, R.K.; Hopkins, D.; Deutsch, B.; Lee, J.; Clay, D.E.; Reese, C.; Malo, D.D.; DeSutter, T.M. Predicting soil electrical conductivity of the saturation extract from a 1:1 soil to water ratio. Commun. Soil Sci. Plant Anaysis 2017, 48 , 2148-2154. [CrossRef]

21. Kargas, G.; Chatzigiakoumis, I.; Kollias, A.; Spiliotis, D.; Massas, I.; Kerkides, P. Soil Salinity Assessment Using Saturated Paste and Mass Soil:Water 1:1 and 1:5 Ratios Extracts. Water 2018, 10, 1589. [CrossRef]

22. Chang, C.; Sommerfeldt, T.G.; Carefoot, J.M.; Schaalje, G.B. Relationships of electrical conductivity with total dissolved salts and cation concentration of sulfate-dominant soil extracts. Can. J. Soil Sci. 1983, 63, 79-86. [CrossRef]

23. Kargas, G.; Londra, P.; Sgoubopoulou, A. Comparison of soil EC values from methods based on 1:1 and 1:5 soil to water ratios and ECe from saturated paste extract based method. Water 2020, 12, 1010. [CrossRef]

24. Slavich, P.G.; Petterson, G.H. Estimating the electrical conductivity of saturated paste extracts from 1:5 soil: Water suspensions and texture. Aust. J. Soil Res. 1993, 31, 73-81. [CrossRef]

25. Vaughn, P.J.; Lesch, S.M.; Corwin, D.L.; Cone, D.G. Water content effect on soil salinity prediction: A geostatistical study using cokriging. Soil Sci. Soc. Am. J. 1995, 59, 1146-1156. [CrossRef]

26. Shirokova, Y.I.; Forkutsa, I.; Sharafutdinova, N. Use of electrical conductivity instead of soluble salts for soil salinity monitoring in Central Asia. Irrig. Drain. Syst. 2000, 14, 199-205. [CrossRef]

27. Khorsandi, F.; Yazdi, F.A. Gypsum and texture effects on the estimation of saturated paste electrical conductivity by two extraction methods. Commun. Soil Sci. Plant Anal. 2007, 38, 1105-1117. [CrossRef]

28. Chi, M.C.; Wang, Z.C. Characterizing salt affected soils of Songnen Plain using saturated paste and 1:5 soil to water extraction methods. Arid Land Res. Manag. 2010, 24, 1-11. [CrossRef]

29. Visconti, F.; de Paz, J.M.; Rubio, J.L. What information does the electrical conductivity of soil water extracts of 1 and 5 ratio $(w / v)$ provide for soil salinity assessment of agricultural irrigated lands? Geoderma 2010, 154, 387-397. [CrossRef]

30. He, Y.; DeSutter, T.; Hopkins, D.; Jia, X.; Wysocki, D. Predicting ECe of the saturated paste extract from value of EC1:5. Can. J. Soil Sci. 2013, 93, 585-594. [CrossRef]

31. Hassannia, M.; Nazari, B.; Kaviani, A.; Sotoodehni, A. Evaluation and analysis of different regression models for estimation of ECe from EC1:5—with a case study from Buin-Zahra, Iran. Irrig. Drainage 2020, 69, 1192-1203. [CrossRef]

32. Zaman, M.; Shahid, S.A.; Heng, L. Guideline for Salinity Assessment, Mitigation and Adaptation Using Nuclear and Related Techniques; Springer Open: Cham, Switzerland, 2018; 164p.

33. Zhang, F.; Tiyip, T.; Ding, J.; Taff, G.N.; He, Q. The effects of the chemical components of soil salinity on electrical conductivity in the region of the delta oasis of Weigan and Kuqa Rivers, China. Agric. Sci. China 2009, 985-993. [CrossRef] 
34. Dierickx, W.R. The salinity and alkalinity status of arid and semi-arid lands. In Land Use Land Cover and Soil Science; Verheye, W., Ed.; EOLSS Publisher: Oxford, UK, 2011; pp. 163-189.

35. Marion, G.M.; Babcock, K.L. Predicting specific conductance and salt concentration in dilute aqueous solutions. Soil Sci. 1976, 122, 181-187. [CrossRef]

36. Letey, J.; Hoffman, G.J.; Hopmans, J.W.; Grattan, S.R.; Suarez, D.; Corwin, D.L.; Oster, J.D.; Wu, L.; Amrhein, C. Evaluation of soil salinity leaching requirement guidelines. Agric. Water Manag. 2011, 98, 502-506. [CrossRef]

37. Khorsandi, F.; Yazdi, F.A. Estimation of saturated paste extracts' electrical conductivity from 1:5 soil/water suspension and gypsum. Commun. Soil Sci. Plant Anal. 2011, 42, 315-321. [CrossRef]

38. Methods of Soil Analysis, 2nd ed.; Agronomy Monograph 9; ASA and SSSA: Madison, WI, USA, 1986.

39. SAS Institute. SAS User's Guide; Version 9.2.; SAS Institute: Cary, NC, USA, 2008.

40. Cui, G.; Lu, Y.; Zheng, C.; Liu, Z.; Sai, J. Relationship between soil salinization and groundwater hydration in Yaoba Oasis, Northwest China. Water 2019, 11, 175. [CrossRef]

41. Van der Zee, S.E.A.T.M.; Shah, S.H.H.; Vervoort, R.W. Root zone salinity and sodicity under seasonal rainfall due to feedback of decreasing hydraulic conductivity. Water Resour. Res. 2014, 50, 9432-9446. [CrossRef]

42. Corwin, D.L.; Yemoto, K. Measurement of soil salinity: Electrical conductivity and total dissolved solids. Soil Sci. Soc. Am. J. 2019, 83, 2558-2574. [CrossRef]

43. Levy, G.J.; Goldstein, D.; Mamedov, A.I. Saturated hydraulic conductivity of semi-arid soils: Combined effects of salinity, sodicity and rate of wetting. Soil Sci. Soc. Am. J. 2005, 69, 653-662. [CrossRef]

44. Tang, S.; She, D.; Wang, H. Effect of salinity on soil structure and soil hydraulic characteristics. Can. J. Soil Sci. 2020. [CrossRef] 